\title{
Importance of Crop Wild Relatives in Climate Resilience
}

\author{
B. Keerthiraj ${ }^{*}$, Anju M. Job ${ }^{2}$, K. S. Shankarprasad ${ }^{3}$, G. S. Sathisha ${ }^{4}$, \\ SadanandKumbar ${ }^{5}$ and C. M. Karthik ${ }^{6}$ \\ ${ }^{1}$ Department of Genetics and Plant Breeding, College of Agriculture, \\ UAHS, Shivamogga-577204, India \\ ${ }^{2}$ Department of Plant Breeding and Genetics, College of Horticulture, \\ KAU, Thrissur-680656, India \\ ${ }^{3}$ Department of Plantation Crops and Spices, College of Horticulture, \\ UHS, Bagalkot-560065, India \\ ${ }^{4}$ Department of Agronomy, College of Agriculture, \\ UAHS, Shivamogga-577204, India \\ ${ }^{5}$ Department of Vegetable science, OUAT, Odisha -751003, India \\ ${ }^{6}$ Department of Agricultural Entomology, College of Agriculture, \\ UAHS, Shivamogga-577204, India \\ *Corresponding author
}

\section{Ke ywords}

Crop wild relatives.

Wild genetic

resources.

Importance of wild

relatives. Crop

improvement

Article Info

Accepted:

22 February 2020

Available Online:

10 March 2020
A B S T R A C T

Inferable from the impressive populace of wild relatives and forebears, the hereditary base of harvests was peaceful wide before taming. Through the span of time, hereditarily uniform improved assortments supplanted the profoundly differing nearby cultivars and landraces. These high yielding assortments have restricted inconstancy to battle the impact of biotic and abiotic stresses not at all like the Crop Wild Relative (CWR), which is an enormous store of agronomically critical characteristics. The usage of qualities from wild hereditary assets (CWR) for harvest improvement is entrenched with essential models going back over a century. In this paper, the data on the significance and use of wild qualities for expanding efficiency, biotic and abiotic stress opposition in major developed harvests is audited. Be that as it may, to use the CWR, surveying the decent variety, recognizing of characteristic of enthusiasm, expanding assorted variety of the distinguished quality and increase the hereditary assets. The usage of wild qualities was restricted to same species because of monotonous methodology in between intersection of species from various quality pools. In any case, with advances in sub-atomic techniques for overseeing backcrossing, bridge crossing, physical hybridization and transgenic approaches there was a spurt in use of wild relatives. Still there might be number of qualities, which are not recognized, can contribute in building up maintainable farming creation. CWR is additionally one among the assets which might not have completely investigated for their agriculturally vital qualities and those qualities will be lost with eradication of CWR. Along these lines, there is an earnest need with CWR recognizable proof as well as in their increase, insurance and their use, which will contribute enormously for guaranteeing nourishment security through adequate generation and accomplishing manageability in agribusiness. 


\section{Introduction}

The global bases of food security are agriculture and plant genetic resources. Plant genetic resources has wide genetic base due to diverse plant material such as landraces, traditional cultivars, wild relatives, other wild species and modern improved varieties. There is an urgent need to increase the level of food production by $60 \%$ with the limited resourcesto meet food requirement of increasing population (FAO, 2012).

It has been estimated that rising temperature, unpredictable rainfall, high frequency of drought and waterlogging events will occur in different parts of the world during 21st century (IPCC, 2014). Therefore, the target of sufficient and sustainable food production becomes more challenging with limited land and water resources.

In order to reach the food requirement level of increasing population, it is important to exploit the available diversity of global plant genetic resources. Genetically narrow based improved modern cultivars are replacing the landraces, local cultivars,and their relatives which were highly diverse andhigh yielding, useful abiotic and biotic stress controlling genes, in traditional agro-ecosystems. The evolution of adaptive cultivars can be achieved through the hybridization techniques in required trait improvement so that the evolution-based varieties will improve the productivity in agriculture (Stebbins, 1950).

In many crop plants developing the genetically higher affinities through identification of CWR cleared the path of breeders to achieve goals of their research by best utilizing the potential genetic variability of wild genetic resources (Sharma et al., 2003). The traits with biotic and abiotic stresses have made CWR a special category of plants for utilization in improvement of cultivated types (Kalloo and Chowdhary, 1992). Some researchers observed that CWR are less vulnerable to genetic erosion, provided their environment is protected (Kalloo and Chowdhary, 1992). Their indiscriminate/over-exploitation for commercial use, largescale deforestation, changing land use are the major causes of depletion of species from nature.

It emphasises that rate of improvement of varieties having wild relative genesis steadily increasing. To combat the effect of climate change in order to achieve the sustainability in agriculture, we need to develop high yielding, climate adapted varieties with high input use efficiency in future. It is further required to enhance the genetic diversity in our production systems to increase resilience of our crops to face new challenges. Though we cannot predict precisely that how the climate change will affect our production systems.

\section{Access to wild genetic resources}

The utilization of CWR requires a multidisciplinary linkage at various levels viz. researchers, conservators, policy makers, partners, local communities and many other end users. The conservation programmes at the regional, national and global levels provide strong recommendations for conservation and use of CWR (Heywood et al., 2008). However, activities such as

Assessment of diversity

Identification of potential traits (characterization)

Collection/augmentation

Multiplication and conservation

Utilization of CWR (Pandey et al., 2004) 


\section{Assessment of diversity}

In Indian species (5,725 endemic taxa) intra, inter-species variation and higher rate of endemism (13) is represented from three major phyto-geographical areas namely Peninsular India (2,015 species), Andaman and Nicobar Islands (239 species) and Himalaya (3,471 species) (Nayar, 1997). Amongst this the most significant component related to crop genepool is the CWR (Arora, 1991).

Including all the centers of diversity such as primary, secondary, teritiary and regional centers of the crops, accounts for more than 485 species (Nayar et al., 2003). The diversity of crop species attained richness due to different and diversed agricultural practices and agro-climatic condition. The diversity of 320 CWR (Arora, 1991) along with wild economic species and weedy taxa that constitute a wild useful genepool.Seven botanical areas/centres have been identified in India: North-Eastern Region, Deccan plateau, Western Peninsular Region, Eastern Himalaya, Western Himalaya, Indus Plains and Upper Gangetic Plains (Arora, 2000). Maximum concentration of species is observed in the North-eastern Region, Western Ghatsand Western Himalaya. The taxonomic identification of CWR based on a knowledge and skill on systematic botany. Thus, collection of wild relatives and other species represents the more number of germplasm collections of many germplasm holdings.

\section{Identification of potential traits (characterization)}

Systematic documentation using passport information generated through exploratory studies, literature, etc. will help in compiling scientific database and updated information on distribution, phenology, ecology, cytological, evolution studies for potential traits, etc., of CWR. Important examples of CWR with identified traits in India are tolerance to marshy/ salinity in a Sundarban delta region of west Bengal in a wild relative Oryza coaractata; In arid region of northwestern track, tolerance to drought and hardiness in Eleusinecompressa awild relativefinger millet; in Himalayas tolerance to cold and chilling injury was identified in wild relative of chick pea; in Western Himalayas resistance to cold and frost was identifies in a wild relative of the linseed i.e, L. perenne; in plateau of Shillong (khasi hills) tolerance to frost and cold was identified in a citrus wild relative.

In many crop species the improvement of its genotype is significantly contributed by semidomesticated, wild relatives and distantly related species majorly in developing countries like India. A major role was contributed by importance of single gene regulating traits which were identified and utilized in crop improvement programmes. We can seean best example of exploitation of single gene regulating trait in an accession of wild tomato for increasing the sugar content in the modern cultivated varieties of tomato (Khoshoo, 1988).

\section{Collection/augmentation}

The germplasm of CWR is augmented through exotic and indigenous sources. The access to indigenous CWR germplasm is through collection that requires considerable skills. Source material (if exotic) requires channelling through specific procedures (import into India as per the provisions of the Plant Quarantine Order 2003). Collection of germplasm of an indigenous material from the source locality (protected habitat or site for endangered/ threatened/ rare species) requires prior permission of the Biodiversity Authorities. 
Collection and conservation of indigenous and exotic plant materials in order to maintain the biological diversity and enrich the genetic base of different cultivated crops is carried out by a national nodal organisation, National Bureau of Plant Genetic Resources (NBPGR) from more than last 3-4 decades. Along with the guidance from 'National Agricultural Technology Project' (NATP) with the theme of 'Sustainable Management of Plant Biodiversity' more than the 200 wild species of 15 different crops were identified, domesticated to enrich the native diversity of the plants to utilize them in the various crop improvement programmes (Pareek et al., 2006). Under the NATP during 1999-2004 more than 23,118 accessions of wild relatives and other species were collected from different phyto-geographical regions of India and conserved, which were belonging to 389 species of 124 genera so that this will be a potential source for crop improvement programmes.

\section{Multiplication and conservation}

One of the serious issues in keeping up the wild relatives and different species which establish a wild germplasm is that the increase of the wild relatives in more up to date spot or environments (where it is ineffectively adjusted). For eg; multiplication and conservation of a wild relative of Vigna under normal field conditions is very much difficult, which the wild relative was collected from Western Ghats. Multiplication, evaluation and characterization should be done at least at 2-3 geographical locations of similar latitude/ longitude for conservation and future utilization. In regional or local basis conservation of collected germplasm can be done through the highly efficient role models like on farm/ in-situ conservation so that the dependence of people on natural stock (wild genetic resources) and involvement of community can be significantly increased.
The active collections of crop wild relatives are evaluated, multiplied, conserved and distributed by a national nodal organisation (NBPGR) through its network between State Agricultural Universities (SAU's), National Research Centres (NRC's) and National Active Germplasm Sites (NAGS). At present the germplasm collection from Indian region represents less contribution for national genebanks. There is an immense urgency to setup germplasm collections missions in order to access and assess the germplasm material from widely dense habitats and conserved through the special efficient conservation models like ex-situ, in-situ and on-farm approaches.

\section{Utilization of CWR}

With the development of interspecific crosses between the crops and wild relatives has paved the way for empowering the exploitation of CWR in various hybridization or crop improvement programmes. The identification of wild relative from Mexico i.e., Zea diploperennis, a new line teosinte (Iltis, 1979) and from India Oryza nivara (Govindaswamy et al., 1966) has increased the value and rate of scope development on the various wild relatives. Utilization of Indian alliums (Indian origin accesions), a new trend, was setted on the achievement of crossability of Allium royeli with the A. cepa and $A$. sativum. The CWR resources have also been utilized as crude product in traditional medicine and traded worldwide in different regions of the globe. For example, Chinese Ginseng (Panex ginseng), from Afghanistan, orchids from India, etc. (Kerry Kate and Laird, 1999).

Lack of awareness of the variable reproductive biology, pattern of variability, aptitude and specific knowledge on identifying the potential of wild material is the cause for the lack of full exploitation of 
them and not emphasizing or nonpopularizing the potential values of wild materials. The more serious problem for utilization of CWR is taxonomic delineation. Conventional germplasm holdings are unable to represent full spectrum of variations and useful trait(s)/ represented in the diversity. Utilization of CWR mainly involves: identifying the wild relatives of crop; screening and evaluation of wild material for potential and desirable traits; using the proper and suitable technique of gene transfer. Based on genetic affinities between the crop species and CWR they can be classified into exploitable and unexploitable types. The primary genepool, first group of wild relatives, comprises the progenitors, wild relatives and even weedy forms of crops (Harlan and de Wet, 1971). Secondary genepool comprises the species which are cross compatible in producing partial fertile genotypes due to their distant relation with the crops. Tertiary genepool comprise the directly unexplainable CWR but they are having beneficial role in carrying or conserving or trapping the desirable genes for many other gene transfer teachings.

By utilizing both traditional techniques such as hybridization or bridge crossing and modern techniques such as molecular techniques and DNA fingerprinting for location specific gene identification in germplasmand somatic hybridization with embryo's rescue or transgenic, can be used to exploit the desired characters. The exploitation of the secondary and tertiary genepool or germplasm has become possible due to application of modern molecular techniques and improved technique of interspecific and bridge hybridization (Hajjar and Toby, 2007). The exploitation of genes from wold relatives is known for more than a century. The rate of introduction of genes from CWR in to related crop species is steadily increased and has met the global food requirement with basic sources i.e. from 'in situ', the farmers' fields and uncultivated land. Majority of new breeding materials or germplasm held in national gene bank, or organizations and the 'in trust' collections are maintained by the International Centres of the CGIAR.

Alireza et al., (2017) reported crop wild relative of wheat such as Triticum urartu, Aegilops neglecta, Ae. cylindrica, Ae. Caudata and Ae. Crassa performed well and yields higher than the check variety (Srivan tolerant control) under induced drought stress condition. The wild relatives of lentil Lens orientalis, L. odemensis, L. lamotteiwere, $L$. ervoides and L. tomentosusfound to be highly tolerant to drought stress than check variety Eston - tolerant control. They were evaluated for the parameter number of seeds per plant and total yield in University of Saskahewan, Canada (Gorim and vandenberg, 2017).The flood tolerant rice genotypes belonging to Agenome possess $S U B 1 A$ gene of the SUB1 locus that confers submergence tolerance through 'escape strategy' up to 14 days of shallow flood waters (Singh et al., 2010). Wild relatives of rice Oryza rhizomatis and $O$. Eichingeri belonging to the $\mathrm{C}$-genome possess SUB1 orthologue, instead of $S U B 1 A$ gene. These wild relatives of rice exhibit submergence tolerance through 'quiescent strategy' and tolerate submergence for over 30 days by deep flood waters (Niroula et al., 2012).Mano and Omari, (2013) developed an introgression line for salt tolerance, MI29/ Zea nicaraguensis(IL29) made from the cross between wild maize line Zea nicaraguensis (flood tolerant)hybridized to cultivated maize variety MI29.

Quan et al., (2018) developed an introgression line, from the wild rice line Dongxiang (O. rufipogon Griff.)population reported for the salt tolerance, having tolerance to salinity, Dongxiang/ Ningjing 15 
(DJ15) hybridised to a rice line under cultivation NJ16 (Oryza sativa L. sspaponica). Annual wild Cicer spp. $C$. pinnatifidum and $C$. Reticulatum are resistance to heat stress (up to $41.8^{\circ} \mathrm{C}$ ) than drought resistant cultivars (Canci and Toker, 2009) under comparison with check variety ICC 4958 as heat and drought tolerant.

\section{List of abiotic and biotic stress tolerance traits of major field crops}

\section{Constraints/ limitations in utilization of CWR}

Varying reproductive biology of wild relatives need to be understood in order to get higher rate of success in plant breeding programmes aimed at developing improved varieties to combat the climate change impacts and perform well.

Due to the poor adaptability of wild relatives to newer habitats, multiplication should be carried out at minimum of 2-3 different geographical regions to ensure survivability of the material for identified specific trait.

In traditional breeding, linkage drag is one of the major problems where, the undesirable gene linked to desirable gene in wild genotypes will also transferred through the hybridization process. The undesirable genes transferred to cultivated genotypes will hinders/ reduce/ decrease the performance of the cultivated genotypes.

In interspecific crosses, hybrid in-viability and sterility are the major constraints in obtaining viable, fertile and vigorous hybrid.

There is lack of strong specific breeding programmes and funding sources.

On the basis of priority of the potential traits of the CWR needs to be augmented, evaluated, characterized and documented for further maintenance and uses. Rare/ endangered plant species of CWR need to be given emphasizes for augmentation, evaluation, conservation and sustainable management through the role models like insitu/ on-farm and ex-situ conservation models. Periodically and in-time monitoring of the CWR status regarding conservation can be carried out through the networking and collaborative approaches from the various institutional links. This monitoring and survey both are successfully and effectively conducted by the Ministry of Environment and Forests, GOI, Botanical Surveys and NGO's.

Table.1 distribution of CWR species in botanical regions of India (Arora, 2000)

\begin{tabular}{|l|l|}
\hline $\begin{array}{l}\text { Phyto-geographical } \\
\text { regions }\end{array}$ & Species \\
\hline Western Ghats & 124 \\
\hline Western Himalaya & 105 \\
\hline Eastern Ghats & 101 \\
\hline Gangetic plains & 82 \\
\hline North-Eastern regions & 53 \\
\hline Indus plains & 42 \\
\hline Eastern Himalaya & 38 \\
\hline Islands & 32 \\
\hline
\end{tabular}


Table.2 CWR in rice

\begin{tabular}{|l|c|}
\hline \multicolumn{1}{|c|}{ Factors } & \multicolumn{1}{|c|}{ Species } \\
\hline Brown plant hopper resistance & $\begin{array}{c}\text { Oryza glaberrima } \\
\text { O. nivara } \\
\text { O. lonistaminata } \\
\text { O. australiensis } \\
\text { O. rufipogon } \\
\text { O. nivara }\end{array}$ \\
\hline Grassy stunt virus resistant & $\begin{array}{c}\text { O. longistaminata } \\
\text { O. rufipogon } \\
\text { O. officinalis } \\
\text { Bacterial blight resistance }\end{array}$ \\
\hline Blast resistance & $\begin{array}{c}\text { O. rufinuta } \\
\text { O. australiensis } \\
\text { O. barthi }\end{array}$ \\
\hline Drought and heat resistance & $\begin{array}{c}\text { O. lonistaminata } \\
\text { O. glaberrima }\end{array}$ \\
\hline O. meridonalis \\
\hline Acidity, Salinity and Cold and frost resistance & O. rufipogon \\
\hline
\end{tabular}

Table.3 CWR in maize

\begin{tabular}{|l|c|}
\hline \multicolumn{1}{|c|}{ Factors } & \multicolumn{1}{|c|}{ Species } \\
\hline \multicolumn{1}{|c|}{ Corn rootworm tolerance } & $\begin{array}{c}\text { Teosinte } \\
\text { Eastern gammagrass }\end{array}$ \\
\hline Army worm tolerance & Zeadiploperennis \\
\hline Spotted stalk borer tolerance & Z. perennis \\
\hline Corn leaf blight, viral disease resisitance & \\
\hline Corn smut resistance & Zeadiploperennis \\
\hline Rust resisitance & Teosinte \\
\hline Drought, Acidity and Salinity resistance & \\
\hline & Eastern gammagrass \\
\hline Water logging resistance & Zea nicaraguensis \\
\cline { 2 - 2 } & Z. luxuris \\
\hline & Eastern gammagrass \\
\hline
\end{tabular}


Table.4 CWR in wheat

\begin{tabular}{|c|c|c|}
\hline Factors & Species & References \\
\hline $\begin{array}{l}\text { Russian wheat aphid } \\
\text { resistance }\end{array}$ & Triticum monoccoccum & Deol et al., 1995 \\
\hline Hessian fly resisitance & Aegilops tsauchii & Suszkiw 2005 \\
\hline Rust resistance & $\begin{array}{l}\text { Triticum turgidum } \\
\text { Aegilops geniculate } \\
\text { Aegilops neglecta }\end{array}$ & $\begin{array}{l}\text { Chhuneja et al., } 2008 \\
\text { Kuraparthy et al., } 2007 \\
\text { Marais et al., } 2009\end{array}$ \\
\hline Powdery mildew resistance & $\begin{array}{l}\text { Triticum monoccoccum } \\
\text { Aegilops geniculata }\end{array}$ & $\begin{array}{c}\text { Yao et al., } 2007 \\
\text { Stoilova and Spetsov, } \\
2006\end{array}$ \\
\hline Dwarf virus resistance & Aegilops geniculata & Zaharieva et al., 2001 \\
\hline Nematode resistance & $\begin{array}{l}\text { Aegilops tsauchii } \\
\text { Aegilops speltoides }\end{array}$ & $\begin{array}{l}\text { Lagudah et al., } 1993 \\
\text { Barloy et al., } 2007\end{array}$ \\
\hline Salt resistance & $\begin{array}{c}\text { Ae. taushii } \\
\text { Ae. comosa } \\
\text { Ae. umbellulata } \\
\text { Ae. cylindrica }\end{array}$ & $\begin{array}{c}\text { Farooq et al., } 1989 \\
\text { Gorham, } 1990 \\
\text { Xu et al., } 1993 \\
\text { Farooq, } 1995\end{array}$ \\
\hline Cold resistance & $\begin{array}{l}\text { Ae. taushii } \\
\text { Ae. umbellulata } \\
\text { Ae. cylindrica } \\
\text { Ae. neglecta }\end{array}$ & $\begin{array}{c}\text { Kiryaan, } 1981 \\
\text { Limin and Fowler, } 1981 \\
\text { Barashkova and Vavilov, } \\
1991\end{array}$ \\
\hline Drought resistance & $\begin{array}{c}\text { Ae. taushii } \\
\text { Ae. sharonensis } \\
\text { Ae. longissimi }\end{array}$ & $\begin{array}{l}\text { Damania et al., } 1992 \\
\text { Waines et al., } 1993 \\
\text { Rekika } \text { et al., } 1998\end{array}$ \\
\hline
\end{tabular}

CWR can thus effectively contribute to broaden the genetic base of agriculturally important traits in crops. This would help us to develop improved genotypes over existing ones, to counteract the major impacts of the changing climate thereby increasing the productivity of crops and ensure the food security and achieving the sustainability in agriculture production with limiting resources.

\section{References}

Alireza, P., Ahmadi, J., Mehrabi, A. A., Etminan, A., Moghaddam, M., and Siddique, K. H. 2017. Physiological responses to drought stress in wild relatives of wheat: implications for wheat improvement. Acta Physiol. Plant 39(4): 106-109.

Arora, R.K. 1991. Plant diversity in the Indian gene centre in Plant Genetic Resources: Conservation and Management. Int. Board for Indian J. Plant Genet. Resour. 25(2): 146-152.

Arora, R.K. 2000. Wild relatives of cultivated plants in Flora of India, Introductory Volume, Part II, Bot. Sur. India. 2(1): 218-234.

Barashkova, E.A. and Vavilov, N. 1991. Physiological-genetic aspects of frost resistance in winter wheat. Relationship of frost hardiness with genome composition in wheat. In Proceedings of the International Symposium: Wheat Breeding-Prospects and Future 
Approaches 2(1): 379-384.

Barloy, D., J. Lemoine, P. Abelard, A. M. Tanguy, R. Rivoal and J. Jahier. 2007. Marker-assisted pyramiding of 2 cereal cyst nematode resistance genes from Aegilops variabilis in wheat. Mol. Breed. 20:31-40.

Canci, H. and Toker, C. 2009. Evaluation of annual wild Cicerspecies for drought and heat resistance under field conditions. Genet. Resour. Crop Evol. 56(1): 1-4.

Chhuneja, P., S. Kaur, T. Garg, M. Ghai, S. Kaur, M. Prashar, N. S. Bains, R. K Goel, B. Keller, H. S. Dhaliwal and K. Singh. 2008. Mapping of adult plant stripe rust resistance genes in diploid A genome wheat species and their transfer to bread w heat. Theor. Appl. Genet. 116:313-324.

Damania, A.B., Hakim, S., and Moualla, M.Y. 1992. Evaluation of variation in Triticum dicoccumfor wheat improvement in stress environments. Hereditas 116(1- 2): 163-166.

Deol, G. S., G. E. Wilde and B. S. Gill. 1995. Host plant resistance in some wild wheats to the Russian wheat aphid, Diuraphisnoxia (Mordvilko) (Homoptera: Aphididae). Plant Breed. 114: 545-546.

FAO [Food and Agriculture Organisation] 2012. Second Global Plan of Action for Plant Genetic Resources for Food and Agriculture, Rome. 21p.

Farooq, S., Asghar, M., Iqbal, N., Askari, E., Arif, M., and Shah, T.M. 1995. Production of salt-tolerant wheat germplasm through crossing cultivated wheat with Aegilops cylindrica-II. Field evaluation of salt-tolerant germplasm. Cereal Res. Commun. 2(1): 275-282.

Farooq, S., Niazi, M.L.K., Iqbal, N., and Shah, T.M. 1989. Salt tolerance potential of wild resources of the tribe Triticeae. Plant and Soil. 119(2): 255-
260.

Gorham, J. 1990. Salt tolerance in the Triticeae: K/ $\mathrm{Na}$ discrimination in Aegilops species. J. Exp. Bot. 41(5): 615-621.

Gorim, L.Y. and Vandenberg, A. 2017. Evaluation of wild lentil species as genetic resources to improve drought tolerance in cultivated lentil. Front. Plant Sci. 8:1129p.

Govindaswami, S., Krishnamurty, A., and Reddy, N.S. 1966. The role of introgression in the varietal variability in rice in Jaypore tract of Orissa. Oryza 3: 74-85.

Hajjar, R. and Hodgkin, T. 2007. The use of wild relatives in crop improvement: A survey of developments over the last 20 years. Euphytica 156:1-13.

Harlan, J.R. and Dewet, J.M.J. 1971. Towards the rational classification of cultivated plants. Taxon. 20: 509-517.

Heywood, V.H., Kell, S.P., and Maxted, N. 2008. Towards a global strategy for the conservation and use of crop wild relatives. $C A B$ Int. 2(1): 657-666.

Iltis, H.H. 1979. Zeadiploperennis (Gramineae): a new teosinte from Mexico. Science. 203 (4376): 186-188.

IPCC [Intergovernmental Panel on Climate Change]. 2014. Fifth Assessment Report: Climate Change 2014, Geneva, Switzerland. 95p.

Kallo, G. and Chowdhary, N. 1992. Distant Hybridization of Crop Plants. Springer. $95 \mathrm{p}$.

Kerry, K., Ten, and Laird, S.A. 1999. The Commercial Use of Biodiversity: Access to Genetic Resources and Benefit- Sharing. Earthscan Publications Ltd. London.

Khoshoo, T.N. 1988. Conservation of biological diversity. In: Plant Genetic Resources - Indian Perspective. National Bureau of Plant Genetic Resources, New Delhi, India. 2(1): 76- 
90.

Kiryan, M.V. and Barashkova, E.A. 1981. Evaluation of winter hardiness and frost resistance in the first and second generations. PI. Br. Abst. 51(1): 9481p.

Kuraparthy, V., P. Chhuneja, H. S. Dhaliwal, S. Kaur, R. L. Bowden and B. S. Gill. 2007. Characterization and mapping of cryptic alien introgression from Aegilops geniculata with new leaf rust and stripe rust resistance genes Lr57 and Yr40 in wheat. Theor. Appl. Genet. 114:1379-1389.

Lagudah, E. S., R. Appels, D. McNeil. and D. P. Schachtman. 1993. Exploiting the diploid D genome chromatin for wheat improvement. In: J. P. Gustafson, R. Appels and P. Raven (Eds.), pp. 87-107. Gene Conservation and Exploitation. Plenum Press, New York.

Limin, A.E. and Fowler, D.B. 1981. Cold hardiness of some relatives of hexaploid wheat. Canadian J. Bot. 59(5): 572-573.

Mammadov, J., Buyyarapu, R., Guttikonda, S.K., Parliament, K., Abdurakhmonov, I., and Kumpatla, S.P. 2018. Wild relatives of maize, rice, cotton, and soybean: treasure troves for tolerance to biotic and abiotic stresses. Front. plant sci. 9(1): 886p.

Mano, Y. and Omori, F. 2013. Flooding tolerance in interspecific introgression lines containing chromosome segments from teosinte (Zea nicaraguensis) in maize (Zea mays ssp. mays). Annals bot. 112(6):1125-1139.

Marais, F., A. Marais, B. McCallum and Z. Pretorious. 2009. Transfer of leaf rust and stripe rust resistance genes Lr62 and Yr42 from Aegilops neglecta Req. ex Betrol. to common wheat. Crop Sci. 49:871-879.

Nayar, E.R., Anjula, P., Venkateswaran, K., Gupta, R., and Dhillon, B.S. 2003. Crop Plants India: A Check-list of Scientific Names. Agro-biodiversity (PGR)-26.
National Agricultural Technology Project on Sustainable Management of Plant Biodiversity, National Bureau of Plant Genetic Resources, New Delhi.

Nayar, M.P. 1997. 'Hot Spots' of plant diversity in India- strategies. In: $P$ Pushpangadan, K Ravi and V Santosh (eds) Conservation and Economic. Evaluation of Biodiversity, Oxford and IBH Publ. House, New Delhi.

Niroula, R. K., Pucciariello, C., Ho, V. T., Novi, G., Fukao, T., and Perata, P. 2012. SUB1A dependent and independent mechanisms are involved in the flooding tolerance of wild rice species. Plant J. 72(2): 282-293.

Pandey, A., Bhandari, D.C., Bhatt, K.C., Pareek, S.K., Tomar, A.K., and Dhillon, B.S. 2004. Wild Relatives of Crop Plants in India: Collection and Conservation. Agro-biodiversity (PGR)41. National Agricultural Technology Project on Sustainable Management of Plant Biodiversity, National Bureau of Plant Genetic Resources, New Delhi.

Pareek, S.K., Bhandari, D.C., Anjula, P., and Dhillon, B.S. 2006. Sustainable Development of Plant Genetic Resources: A Success Story. Agrobiodiversity (PGR)-59. National Agricultural Technology Project on Sustainable Management of Plant Biodiversity, National Bureau of Plant Genetic Resources, New Delhi.

Quan, R., Wang, J., Hui, J., Bai, H., Lyu, X., Zhu, Y., Zhang, H., Zhang, Z., Li, S., and Huang, R. 2018. Improvement of salt tolerance using wild rice genes. Front. Plant Sci. 156(8): 2269-2280.

Rekika, D., Nachit, M.M., Araus, J.L., and Monneveux, P. 1998. Effects of water deficit on photosynthetic rate and osmotic adjustment in tetraploid wheats. Photosynthetica. 35(1): 129-138.

Sharma, H.C., Pampathy, G., and Reddy, L.J. 2003. Wild relatives of pigeon pea as a 
source of resistance to the pod fly (Melanagromyza obtuse, Malloch) and pod wasp (Taraostignodescajanianae $\mathrm{La}$ Salle). Genet. Resour. Crop Evol. 50: 817-824.

Singh, N., Dang, T. T., Vergara, G.V., Pandey, D. M., Sanchez, D., Neeraja, C. N., Septiningsih, E. M., Mendioro, M., Tecson-Mendoza, E. M., Ismail, A. M., and Mackill, D. J. 2010. Molecular marker survey and expression analyses of the rice submergence-tolerance gene SUB1A. Theor. Appl. Genet. 51(8): 1114.

Stebbins, G.I. 1950. Variation and Evolution in Plants. Columbia Univ. Press, New York, USA.

Stoilova, T. and P. Spetsov. 2006. Chromosome 6U from Aegilops geniculataroth carrying powdery mildew resistance in bread wheat. Breed. Sci. 56:351-357.

Suszkiw, J. 2005. Hessian fly-resistant wheat germplasm available Agricultural
Research Service, News and Events, United States Department of Agriculture

Xing, X., Monneveux, P., Damania, A.B., and Zaharieva, M. 1993. Evaluation for salt tolerance in genetic resources of Triticum and Aegilops species. Bulletin des RessourcesGenetiquesVegetales (CIRP/FAO); Noticiario de RecursosGeneticosVegetales (CIRF/FAO).

Yao, G., J. Zhang, L. Yang, H. Xu, Y. Jiang, L. Xiong, C. Zhang, Z. Zhang, Z. Ma and M. E. Sorrells. 2007. Genetic mapping of two powdery mildew resistance genes in einkorn (Triticum monococcum L.) accessions. Theor. Appl. Genet. 114:351-358

Zaharieva, M., P. Monneveux, M. Henry, R. Rivoal, J. Valkoun, and M. M. Nachit. 2001. Evaluation of a collection of wild wheat relative Aegilops geniculata Roth and identification of potential sources for useful traits. Euphytica 119:33-38

\section{How to cite this article:}

Keerthiraj. B., Anju M. Job, K. S. Shankarprasad, G. S. Sathisha, SadanandKumbar and Karthik. C. M. 2020. Importance of Crop Wild Relatives in Climate Resilience. Int.J.Curr.Microbiol.App.Sci. 9(03): 2922-2932. doi: https://doi.org/10.20546/ijcmas.2020.903.336 